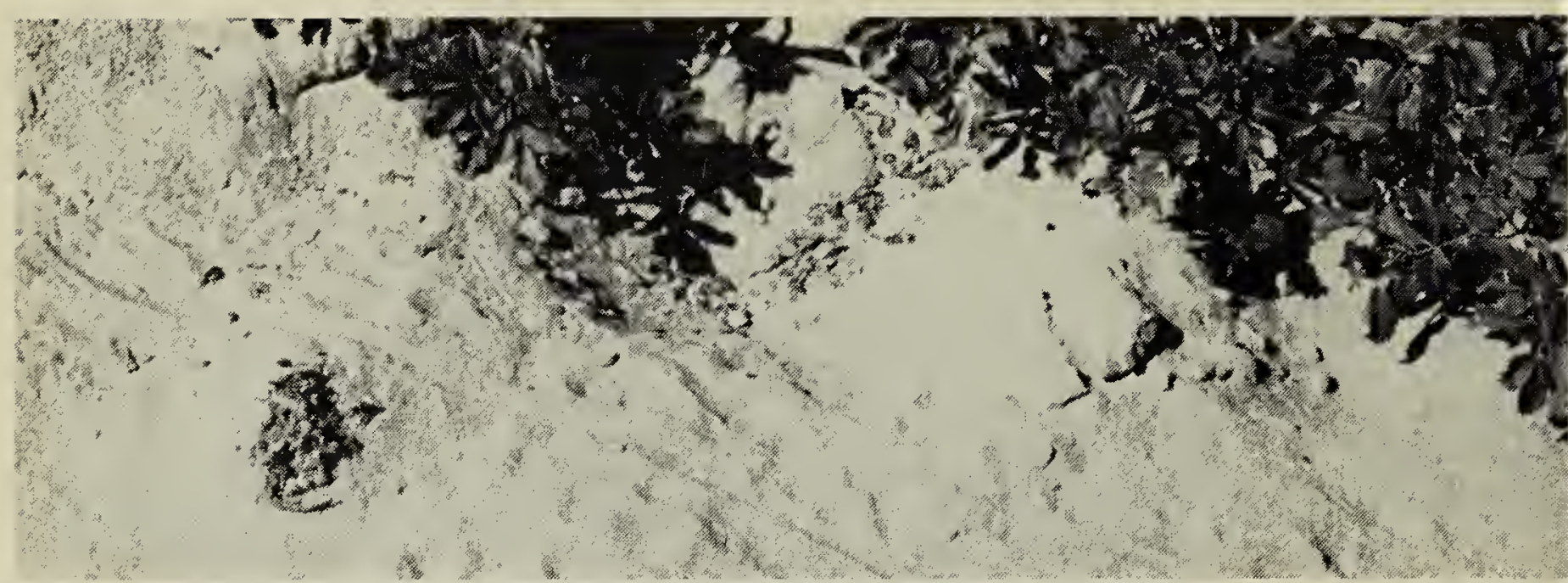

Kangaroo rat tracks near Burstall, 3 September 79

David Baron

\section{EVIDENCE OF KANGAROO RATS NEAR BURSTALL, SASKATCHEWAN}

DAVID BARON, Division of Natural History Research, Saskatchewan Museum of Natural History, Regina, Saskatchewan, S4P 3V7.

Ord's kangaroo rat (Dipodomys ordii) is a small, nocturnal burrowing rodent of the arid plains areas of western North America. Its reduced fore limbs, greatly enlarged hind limbs and long tail are adaptations to a bounding gait, and give the species a kangaroo-like appearance.

The first Saskatchewan specimen of Ord's kangaroo rat was found at Shackleton in 1933. ${ }^{1}$ Later, Nero and Fyfe located colonies of the species in the Great Sand Hills south of Sceptre. $^{2}$ They also reported evidence of kangaroo rats in a large dune west of Mendham. In Alberta a large colony was found about $49 \mathrm{~km}$ southwest of Empress. ${ }^{3}$ These animals had colonized a roadside in a grassland area.

In September 1979 staff of the Saskatchewan Museum of Natural History made a field trip to the Great Sand Hills to reconnoiter areas with habitat suitable for supporting a population of kangaroo rats. In con- junction with this study, the active sand dune area approximately $6 \mathrm{~km}$ north of Burstall was investigated on 3 September 1979. The area examined (Sec. 14-20-29-W3) consists mainly of stabilized dunes vegetated with grasses and shrubs, such as rose (Rosa sp.) and hoary sagebrush (Artemisia cana), but several active dunes are present. Three dunes in an area approximately $1 \mathrm{~km}$ square were examined and many tracks and recent burrows of Ord's kangaroo rat were observed on each dune. The most common vegetation in the area of the animals' activity was lanceleaved psoralea (Psoralea lanceolata) and Wood's rose (Rosa woodsii). Burrows were not detected in the surrounding grassland areas.

The kangaroo rat colonies in the Burstall dunes are approximately 13 $\mathrm{km}$ southwest of the colony reported near Mendham ${ }^{2}$ and $40 \mathrm{~km}$ east of that reported by Smith and Hampson ${ }^{3}$ and fall within the expected range of the species in Canada.

${ }^{1}$ NERO, R.W. 1956. The kangaroo rat in Saskatchewan. Blue Jay 14:3-4.

${ }^{2}$ NERO, R.W. and R.W. FYFE. 1956. Kangaroo rat colonies found. Blue Jay 14:176-179.

${ }^{3}$ SMITH, H.C. and M.J. HAMPSON. 1969. A kangaroo rat colony in Alberta. Blue Jay 27:224-225. 